\title{
Malamangala Kavi's Malayalam Naishadha in Our Language
}

Malamangala Kavi, writing in Malayalam (in the so-called Rubies and Coral style, mixing Sanskrit and Malayalam) in the sixteenth or early seventeenth century, shows us a slightly earlier moment in Nala's passionate imagination of Damayanti in his Naishadha in Our Language. These two people have fallen in love with one another by hearsay; it will take some time (and the help of the talking goose) before they actually meet. Nonetheless, one could argue, as Malamangala Kavi seems to, that their mutual imaginings provide them with their most fulfilling moments. This poet belongs to the creative period in which the self-awareness of Malayalam as a distinct and autonomous literary language was crystalizing.

MALAMANGALA KAVI'S NAISHADHA IN OUR LANGUAGE (1.22-23, $29-31,33,35,37,39-40$ )

[Nala and Damayanti can't sleep:]

First they drew from the depths of their hearts the person newly loved, and very beautiful. Then they placed him or her before them with the help of their imaginations, doing away with all other thoughts. Thus they happily fulfilled their desires, obsessively practiced and repeated, as little by little they submerged themselves in an ocean of joy. (1.22)

The goddess Sleep came to them over and over, but each time she thought to herself, "I'm not about to create an obstacle 
to the intense joy they're feeling

by making love in their imagination"-

so each time she went away,

as a tactful friend should. (1.23)

[Nala, lovesick, tries to divert himself in his garden:]

Puffs of wind were scooping up and scattering

dust of pollen, more and more,

blowing them here and there,

but what was amazing was the way

they lit the fire of love

in his heart

like the dry sap of the payin tree

that bursts into flame when you blow on it. (1.29)

In that garden, the generals of Desire-

the cuckoos and others-taking note of Nala's

long-standing, bitter enmity with their master

and imagining, in their minds, that this was the last

chance Desire could defeat him, issued a clarion call

to a final, fateful battle. (1.30)

They poured out sweet sounds

to the utmost limit of what a person

can hear, as if twisting red-hot rods

heated in rage by Love

in his two ears. (1.31)

Rows of trees were awash in torrents

of fresh honey, far sweeter than fresh milk

and heavy with the thrill of passion,

like a cloudburst aimed at killing

all on earth who were in love. (1.33)

Inside himself, he couldn't bear it-this awkward

and violent state. The fire of desire hit

the summit and kept on getting worse.

"It was a big mistake to come here," he thought.

"What misery." Everything his heart had once desired

now made him turn away. It was all because of that

princess who had robbed him of his heart. (1.35)

"Love's fire flares higher, generating ash

and more ash, rising up to the heights. 
By comparison, dying would be easy.

Isn't there someone, anyone, some good soul who now, or later, would touch my chest and utter the great mantra that is Damayanti's name, saying it slowly and sweetly so that love wouldn't hurt so much?” (1.37)

"My dear delicate gust of wind: I hope you're well. As for me, it's time to die. But I still have one wish that I can't help but tell you. Go at once to the city called Kundinapura. Come to rest in Damayanti's sweet hair. There's a feast waiting for you there. Enjoy it, and come back soon.” (1.39)

"It's stupid that I should be talking to this disembodied being, the wind. There's nobody listening to my sad story. No one but me and the wind outside. I've heard that when the power of desire reaches down into the depths of the mind, lovers speak their delusion." (1.40)

\section{TALK TO THE WIND: MALAMANGALA KAVI'S NAISHADHA IN OUR LANGUAGE}

\section{Sivan Goren-Arzony (Near Reader)}

What does it take to fall in love? And how much input is needed for love to develop into one of those scorching, all-consuming fires? Nala and Damayanti's love story, first told in the Mahabharata epic and then retold time and again in a variety of genres and languages in South Asia, depicts one such burning love initiated only by words. But to say "only" might be misleading in this case. For speech in South Asia's many literary cultures is a uniquely powerful entity, even a divinity. It is capable not only of making two people who have never met fall desperately in love, but also of conveying their story in such a compelling and powerful way that listeners and readers experience a singular sense of happiness, even if, like us, they are removed from it by hundreds of years.

The verses David Shulman selected and translated from Malamangala Kavi's Naishadha in Our Language share this power. They were written around the late sixteenth century in the region of Kerala, located on the western tip of the Indian peninsula. Like much of Kerala's medieval poetry, Naishadha in Our Language was composed in the Rubies and Coral style (Manipravālam), a blend of Sanskrit and Kerala's local language (which later came to be known by the name Malayalam). As the name suggests, the decision to narrate the Nala and Damayanti story in a 
local idiom was self-conscious: a bold response to one of the most beautiful and complex poems ever to be written in Sanskrit, Shriharsha's twelfth-century Life of Naishadha.

What was Malamangala Kavi's motivation for this composition? Was he trying to simplify Shriharsha's formidable text and present it to an audience less versed in Sanskrit? This was probably not the case since to read the Naishadha in Our Language, or, for that matter, any work in this unique linguistic concoction, requires the command of both Sanskrit and Kerala's local language. Rather, I believe, it was his faith in this idiom, both its rubies and its coral, that prompted him to convey an old story in new and appealing ways.

The Nala and Damayanti story is extremely popular in South Asia, and thus it is common knowledge that this couple fell in love by merely hearing of one another. But how could this happen? Malamangala Kavi turns our attention to the couple's inner world and allows us to see that it was in their imaginations that this took place. There, a meticulous process of visualization unfolds: first, each seizes the newly loved person from the bottom of their hearts; then each places the other in front of them, shaking off all other thoughts; finally, they make love so intensely that even Sleep lets them be. In other words, dreaming makes way for daydreaming and external reality makes way for an inner life that becomes the couple's central mode of being. The contrast between imagination and sleep, two mental states that are commonly bound together and that are both different from our "normal" daily perception, is more than just a literary turn. Malamangala Kavi's words are like a lamp thrust into a dark room, to adapt Dandin's famous analogy for language, and they allow us to see for ourselves what is really happening inside Nala and Damayanti's minds.

The next verses describe an almost fatal mistake on the part of Nala. As a reader of Sanskrit poetry (which, as we see next, he most certainly was), Nala should have known that for a lovesick man, the garden is a dangerous place full of unbearable sensual pain. This is a common motif in the extremely prolific South Asian genre of "messenger poetry." In messenger poems, lovers who are separated by life's harsh circumstances send messages to their faraway beloveds, often using odd go-betweens such as a cloud, the breeze, a bee, or some bird or another. In this sense, the Nala and Damayanti story with its episode of sending a goose as an envoy is already linked to the genre of messenger poems. In the literary messages sent to their lovers, generations of forlorn characters have portrayed pleasant and passion-inducing elements such as the cry of the cuckoo, cool moonbeams in the middle of the night, and the mild, fragrant southern wind as dangerously unbearable in their current situation. Malamangala Kavi animates these elements as "the generals of Desire," who are unwilling to let their lord's bitter enemy, now that he has finally set foot in their territory, escape with his life. The nature of this bitter enmity, explains the commentator, lies in the fact that Nala is so beautiful that he outshines Desire, the god of Love, known for his beauty. He is, in fact, "the agitator 
of the world's agitator (Love) before our very eyes." ${ }^{1}$ Love surely seems agitated to act, then, and so are his "generals."

The four verses starting with 1.31 (not all are translated here) depict attacks on four of Nala's senses: hearing (31), sight (32), taste (33), and smell (34). All four verses end the same way with similes that exemplify Nala's dire state: just as "twisting red-hot rods," just as "a cloudburst aimed at killing," and so on. Taken together, the four verses are a cohesive unit that consists of a direct unfolding assault on Nala's senses.

Moreover, and this is something that cannot be gotten from any translation, there is a clear divide between the two verses describing Nala and Damayanti's lack of sleep (1.22-23), and the four depicting the attack on Nala's senses (1.3134). In terms of lexicon and morphology, the former pair is entirely in Sanskrit, while the latter set of four is almost entirely in Malayalam, the language of Kerala, with only an occasional touch of Sanskrit. So even in the Rubies and Coral combination, there are variations: sometimes we find more rubies, other times more coral.

But let me return to the passage at hand. Verse 1.35 opens a new section in the narrative (something also signaled, in the original, by a change in meter). The campaign of Love's generals has turned out well, and Nala is on the brink of defeat. Now we hear his own words as he realizes that his short stroll in the garden has turned into a disaster for him. A common South Asian literary template describes love in separation as a gradual process of an intensification of one's mental and physical pain that culminates in death. Nala is fully aware of this and gives voice to this process as he himself experiences it. In verse 1.37, for instance, this intensification is expressed by a verbal chain that abounds with repetitions: Love's fire "flares higher, generating ash / and more ash, rising up to the heights."

In his anguish, Nala desperately looks for some relief. At this very moment, the poem turns, once again, into messenger mode: Nala talks to a "delicate gust of wind" and asks it to travel to Damayanti's town Kundina, enjoy a "feast" in her hair, and return scented. Will this fragrant wind, once back from Damayanti's hair, be a life-saving remedy for Nala? Or perhaps this is merely another death wish, also to be executed by Love's generals? As is common in messenger poetry, we never get that far. The sender asks the courier to carry the message, but whether it is delivered or not is typically left for the readers' imagination.

Indeed, Nala immediately reflects on his act of talking to the wind, "this disembodied being," and comes to see it as strange because there is no one actually "listening to my sad story." Yet here Nala reveals himself not only the hero of a messenger poem, but also a reader of such poetry. He thus finds comfort in a paraphrase from one of the most famous verses in all of Sanskrit poetry, the fifth verse of Kalidasa's prototypical messenger poem, the Cloud Messenger (Meghadūta). "I've heard," Nala remembers, "that when the power of desire reaches down into / 
the depths of the mind, lovers / speak their delusion" (1.40). In fact, the original highlights the fact that this is something that happens to all those who are in love (akhila-kāminām). This comforting thought, which comes straight from a metapoetic reflection in Kalidasa's poem, encourages Nala to continue his seemingly irrational behavior. In the very next verse (which is not part of the selection), he asks a mango tree to bid farewell to its own lover in the form of a creeper, and then rush to Damayanti to tell her all about his (Nala's) misery.

Kalidasa's words, then, frame Nala's understanding of his own feelings. We could even say that Malamangala Kavi portrays a hero who is to some extent aware of himself as a literary character, much as Cervantes did with Don Quixote. More depth is added by the temporal looping taking place here: Nala, a character from the ancient epic, the Mahabharata, understands his actions through a verse from Kalidasa, a fifth-century poet and playwright who is situated far in the future from the epic's perspective. Such playful intertextual moments also reveal the intimacy that the language of Rubies and Coral shares with Sanskrit poetry. The whole system of texts has been submerged in it through allusions and quotations for the purpose of creating a literature that is nonetheless entirely new.

In early works in Rubies and Coral, one can sense an anxiety to keep Sanskrit in check; this is most clearly expressed in The Mark of Lady Grace (Lilātilakam; fourteenth century?), the pioneering manifesto of this new form of literature. In Malamangala Kavi's poem, however, this anxiety is no longer present. Here, Sanskrit and Kerala's language are playfully bound together, syntactically, thematically, and temporally, to create a poem in which the linguistic borders become obscure and irrelevant.

In the very final verse quoted here, Nala is aware that there is no one to hear his "sad story." This is not only the regret of a lover who has no one to turn to (one goose, a delicate wind, and a certain mango tree notwithstanding), but perhaps also that of a poet, wishing that his beautiful verse be heard outside of himself. David Shulman's short selection enables readers who don't read Sanskrit, Malayalam, or their unique combination in Rubies and Coral to imagine just how powerful this poetry can be. Shulman has always been a "delicate gust of wind," ready to pay attention, listen, and spread the beauty of the words he has heard.

\section{IN THE GARDEN OF LOVE: AN ESSAY ON NAISHADHA \\ IN OUR LANGUAGE \\ Meir Shahar (Far Reader)}

Many years ago I had the privilege of being David Shulman's student. As a Hebrew University undergraduate, I took several of his introductory classes to Sanskrit language and literature. The attraction of the Indian creative imagination 
notwithstanding, my academic career carried me elsewhere. I chose to specialize in Chinese literature, and it is the latter that offers me clues for understanding a Malayalam poem. In the brief essay that follows, I compare the Naishadha in Our Language to one of the greatest works of Chinese romantic literature, The Peony Pavilion. The Malayalam poet Malamangala Kavi and his Chinese counterpart Tang Xianzu are equally concerned with the role of mental construction in the experience of love, and their respective protagonists languish from desire to creatures of their own imaginings. Another theme that unites the two works is the centrality of the blossoming garden as the setting and metaphor for love.

Composed at approximately the same period as Naishadha in Our Language, The Peony Pavilion (Mudan ting) is considered among the greatest works of Chinese romantic literature. It is a play-or more accurately an opera-whose verses were intended for singing and reading alike. Contemporaneous with Malamangala Kavi, its author Tang Xianzu (1550-1616) designed it as an exploration of the power of love. Like Malamangala Kavi's Nala, Tang's heroine Du Liniang is brought by love sickness to the brink of death. Unlike Nala, she actually perishes from unfulfilled desire, only to be brought back to life by the force of reciprocal love. Having descended to the netherworld, she is summoned back to the world of the living by the tender supplications of her beloved. In Tang's masterpiece, love is not only as strong as death; it is stronger.

In the Naishadha in Our Language and The Peony Pavilion alike, the battle of love is fought in a blooming garden. The Indian and the Chinese Cupids accomplish their mission by leading their amorous prey to flourishing groves where the radiance of blossoming flowers and the music of warbling birds engender desire. The Indian god of love, Kamadeva, pierces his victims' hearts with flowery arrows shot from a bow made of sugarcane with a string fashioned of honeybees. He lies in wait for his innocent prey amidst flowering trees that intoxicate. He attacks them with legions of singing birds that beguile the senses:

They poured out sweet sounds

to the utmost limit of what a person

can hear, as if twisting red-hot rods

heated in rage by Love

in his two ears. (1.31)

Like his Indian counterpart, the Chinese Eros sows the seeds of love in a budding grove. In The Peony Pavilion he is identified as a Flower Spirit, who lures his hunt in the season of their bloom. The spring is the time of love, the very word being synonymous in Chinese with desire: "Spring feeling" (chunqing) is love, and "spring intention" (chunyi) is desire. When the meadows are filled with colorful blossoms, and the bees and butterflies chase each other in erotic pirouettes, the Flower Spirit stabs his victims with the agony of unrequited love. The beauty of the season brings no joy to the tormented lovers. On the contrary, it serves to 
intensify the pain of unbearable desire, as if nature is intent on simultaneously titillating and mocking its helpless prey. Here is how Flower Spirit describes his mission as he appears on the stage of The Peony Pavilion:

[I am the] Commissioner of the Flowers' Blooming,

come with new [Spring] season

from Heaven of Blossom Guard

to fulfill springtime's labors.

Drenched in red petal rain

the beholder, heart-sore,

anchors his yearnings

amid the clouds of blossom. ${ }^{2}$

No wonder that the garden excursion brings no relief to Nala and Du Liniang. The blooming park that was thought to assuage the pangs of desire turns out to intensify them. The blossoming flowers and chirping birds do not slake the thirst that they themselves arouse. The riotous colors of spring contrast with the lover's drab loneliness. "It was a big mistake to come here . . . what misery," laments Nala. "Bright the morn, lovely the scene, listless and lost the heart" concurs his Chinese counterpart. "Ah Heaven," she cries, "I begin to realize how disturbing the spring's splendor can truly be. They were all telling the truth, those poems and ballads I read that spoke of girls of ancient times 'in springtime moved to passion, in autumn to regret."'3 The cravings wrought by the beauty of the flourishing garden are insatiable. Nature engenders desire, even as it is indifferent to the torments of those inflicted by it.

In the Chinese case, the anguish of the spring scene is twofold. Even as she is tormented by spring fever, Du Liniang laments the season's decay. The cravings wrought by the beauty of the flourishing park are inseparable from the pain of its imminent demise. Reading herself into the flowers, Du Liniang mourns their future withering at the very moment of their bloom. In the prime of her youth, the heroine laments her future fading. The tradition of mourning for fallen blossoms runs through Chinese literature. The greatest Chinese novel has its heroine bury them lest they be trodden upon by unfeeling feet. In Cao Xueqin's Dream of the Red Chamber (Honglou meng; ca. 1760), Daiyu goes rake in hand into the blooming garden to collect the fallen petals. She accompanies her lyrical task by a poem on her own sad fate:

The blossoms fade and falling fill the air,

Of fragrance and bright hues bereft and bare.

Floss drifts and flutters round the Maiden's bower,

Or softly strikes against her curtained door.

The Maid, grieved by these signs of spring's decease,

Seeking some means her sorrow to express, 
Had rake in hand into the garden gone,

Before the fallen flowers are trampled on.

Can I, that these flowers' obsequies attend,

Divine how soon or late $m y$ life will end?

Let others laugh flower-burial to see:

Another year who will be burying me?

As petals drop and spring begins to fail,

The bloom of youth, too, sickens and turns pale.

One day, when spring has gone and youth had fled,

The maiden and the flowers will both be dead. ${ }^{4}$

The resonance of the Naishadha in Our Language and The Peony Pavilion extends from the imagery of the garden to the centrality of mental construction in the experience of love. Nala and Du Liniang both fall in love long before they ever meet the objects of their desire. In this respect, the Malayalam and the Chinese poets similarly explore the origins of love in the depths of one's self. Malamangala Kavi and Tang Xianzu shy not from emphasizing that their protagonists are enamored of the creatures of their own imagination. Nala is brought to the brink of death by love sickness to a woman he never met face to face, and Du Liniang perishes from unrequited cravings for a man that appeared in her dreams alone. That they are figments of the imagination does not diminish the pain of longing for them. Psychologically, the imagined beloved is as real as the flesh and blood one. It might even be argued - to quote the title of one of David Shulman's booksthat he or she is More than Real. ${ }^{5}$

In the verse, the word imagination reveals that the object of love is not a flesh and blood person but a mental construction. Malamangala Kavi tells us that Nala and Damayanti "drew from the depths of their hearts / the person newly loved ... Then they placed him or her before them / with the help of their imaginations" (1.22). The Malayalam poet goes on to describe the pleasures of fanciful lovemaking, as delicious as-if not more so-than the meeting of carnal bodies. Sleep refrains from intervening with the lovers' chimeric encounters lest he disrupts "the intense joy they're feeling / by making love in their imagination" (1.23).

In the Chinese play, the idiom of "dream" (meng) is used to convey the agency of the self in the creation of the beloved. Tang Xianzu has his heroine fall in love with a man (Liu Mengmei) who is revealed to her in her dreams. Du Liniang perishes out of lovesickness for a person whom she never meets in real life. And yet the dream comes true: the creature of the imagination turns out to be a real person. Miraculously, the object of Du Liniang's reveries simultaneously envisages her. Liu Mengmei dreams of Du Liniang, just as she dreams of him. Arriving at her former residence and discovering the self-portrait she left behind, he is convinced of the veracity underlying his fantasy. He resolves to call upon the 
goddess of his dreams and the two engage in imaginary lovemaking, "a mating of shadows, consummation within the mind."' Their mutual devotion is such that it moves the judges of the netherworld to pity. Du Liniang is brought back to life and the meeting of shadows turns into the lovemaking of real persons.

Tang Xianzu's preface to his masterpiece reveals his primary concern with the role of mental constructions in the experience of love. The opening words of The Peony Pavilion challenge the distinction between dream and reality in the realm of emotions:

Among all the amorous young women of this world, is there anyone comparable to Du Liniang? Having dreamed of her beloved, she fell ill. Her illness grew severe, so much so that she drew her self-portrait and died. She was dead for three years. Then, from the depths of the netherworld she sought the object of her dreams, coming back to life. A person such as Du Liniang might truly be said to have experienced genuine love. The origins of love are unknown. Having appeared, it deepens. Love might lead a person to his death, and it might bring a dead person back to life. If the living are not driven by it to death, and the dead are not brought by it back to life, it is not utmost love. And why should not the love in a dream be real? Aren't there many people in the world who are moved by dreams?

Alas! The affairs of the human world surpass human comprehension. Since we are not geniuses, we employ logical principals (li) as our yardstick for everything. By logical principals, Du Liniang's story is unreal. However, by the standards of love it might be real. Who knows??

I have relied upon the example of The Peony Pavilion to highlight two aspects that - as a far-removed reader-struck me in Malamangala Kavi's Naishadha in Our Language: the imagery of the garden and the significance of the imagination in conjuring the beloved's image. It might be fitting to conclude my brief comments with an allusion to another poetic tradition in which David Shulman is versed. Writing some two thousand years before Malamangala Kavi and Tang Xianzu, the Hebrew author of the Song of Songs (also known as the Song of Solomon) was, like them, obsessed with the crushing power of love: "Love is as strong as death; jealousy is cruel as the grave," he observes. The biblical verse and the Malayalam poem similarly draw upon the metaphor of fire to render the vehemence of consuming desire: "Mara's fire flares higher, generating ash / and more ash, rising up to the heights. / By comparison, dying would be easy," laments Nala (1.37). "The flashes of love are flashes of fire, a most vehement flame. Many waters cannot quench love, neither can floods drown it," concurs the ancient Hebrew poet. ${ }^{8}$

In the Song of Songs-as in Naishadha in Our Language and The Peony Pavilion-the blooming garden is the site of the erotic encounter. But it is more than that. The tempting grove functions not only as the physical location of the lover's tryst, but also as a metaphor for their very bodies. She is his private garden, 
and he is her secluded grove. He eats her luscious fruits, and she slakes her thirst in his embrace. He sings:

I come to my garden, my sister, my bride,

I gather my myrrh with my spice,

I eat my honeydew with my honey,

I drink my wine with my milk.

And she responds:

As an apple tree among the trees of the wood, so is my beloved among young men.

With great delight I sat in his shadow and his fruit was sweet to my taste. 